\title{
Severe thrombophilia in a factor V-deficient patient homozygous for the Ala2086Asp mutation (FV Besançon)
}

Citation for published version (APA):

Castoldi, E., Hézard, N., Mourey, G., Wichapong, K., Poggi, M., Ibrahim-Kosta, M., Thomassen, M. C. L. G. D., Fournel, A., Hayward, C. P. M., Alessi, M-C., Hackeng, T. M., Rosing, J., \& Morange, P-E. (2021). Severe thrombophilia in a factor V-deficient patient homozygous for the Ala2086Asp mutation (FV Besançon). Journal of Thrombosis and Haemostasis, 19(5), 1186-1199. https://doi.org/10.1111/jth.15274

Document status and date:

Published: 01/05/2021

DOI:

$10.1111 /$ jth. 15274

Document Version:

Publisher's PDF, also known as Version of record

Document license:

Taverne

Please check the document version of this publication:

- A submitted manuscript is the version of the article upon submission and before peer-review. There can be important differences between the submitted version and the official published version of record.

People interested in the research are advised to contact the author for the final version of the publication, or visit the DOI to the publisher's website.

- The final author version and the galley proof are versions of the publication after peer review.

- The final published version features the final layout of the paper including the volume, issue and page numbers.

Link to publication

\footnotetext{
General rights rights.

- You may freely distribute the URL identifying the publication in the public portal. please follow below link for the End User Agreement:

www.umlib.nl/taverne-license

Take down policy

If you believe that this document breaches copyright please contact us at:

repository@maastrichtuniversity.nl

providing details and we will investigate your claim.
}

Copyright and moral rights for the publications made accessible in the public portal are retained by the authors and/or other copyright owners and it is a condition of accessing publications that users recognise and abide by the legal requirements associated with these

- Users may download and print one copy of any publication from the public portal for the purpose of private study or research.

- You may not further distribute the material or use it for any profit-making activity or commercial gain

If the publication is distributed under the terms of Article $25 \mathrm{fa}$ of the Dutch Copyright Act, indicated by the "Taverne" license above, 


\title{
Severe thrombophilia in a factor V-deficient patient homozygous for the Ala2086Asp mutation (FV Besançon)
}

\author{
Elisabetta Castoldi ${ }^{1}$ | Nathalie Hézard ${ }^{2}$ | Guillaume Mourey ${ }^{3}$ | Kanin Wichapong $^{1}$ | \\ Marjorie Poggi ${ }^{4} \odot \mid$ Manal Ibrahim-Kosta ${ }^{4} \mid$ M. Christella L. G. D. Thomassen ${ }^{1}$ | \\ Alexandra Fournel $^{3}$ | Catherine P. M. Hayward ${ }^{5} \odot$ | Marie-Christine Alessi ${ }^{4} \odot$ | \\ Tilman M. Hackeng $^{1}$ | Jan Rosing ${ }^{1}$ | Pierre-Emmanuel Morange ${ }^{4}$ ()
}

${ }^{1}$ Department of Biochemistry, Cardiovascular Research Institute Maastricht (CARIM), Maastricht, The Netherlands

${ }^{2}$ Laboratory of Haematology, La Timone Hospital, Marseille, France

${ }^{3}$ Department of Clinical Hemostasis, University Hospital of Besançon,

Besançon, France

${ }^{4} \mathrm{C} 2 \mathrm{VN}$, INSERM, INRA, Aix Marseille University, Marseille, France

${ }^{5}$ Pathology and Molecular Medicine, McMaster University, Hamilton, ON, Canada

Correspondence

Pierre-Emmanuel Morange, Haematology Department, CHU Timone, 264 Rue SaintPierre, 13385 Marseille Cedex 05, France. Email: pierre.morange@ap-hm.fr

Funding information

Canadian Institutes of Health Research (CIHR), Grant/Award Number: MOP 133474

\begin{abstract}
Background: Coagulation factor $\mathrm{V}(\mathrm{FV})$, present in plasma and platelets, has both proand anticoagulant functions.

Objective: We investigated an FV-deficient patient (FV:C 3\%, FV:Ag 4\%) paradoxically presenting with recurrent venous thrombosis (11 events) instead of bleeding.

Methods/Results: Thrombophilia screening revealed only heterozygosity for the F2 20210G >A mutation. Although thrombin generation in the patient's platelet-poor plasma was suggestive of a hypocoagulable state, thrombin generation in the patient's platelet-rich plasma (PRP) was higher than in control PRP and extremely resistant to activated protein C (APC). This was partially attributable to the complete abolition of the APC-cofactor activity of FV and a marked reduction of plasma tissue factor pathway inhibitor antigen and activity. The patient was homozygous for a novel missense mutation (Ala2086Asp, $\mathrm{FV}_{\text {Besançon }}$ ) that favors a "closed conformation" of the C2 domain, predicting impaired binding of $F V(a)$ to phospholipids. Recombinant $F V_{\text {Besançon }}$ was hardly secreted, indicating that this mutation is responsible for the patient's FV deficiency. Model system experiments performed using highly diluted plasma as a source of $\mathrm{FV}$ showed that, compared with normal $\mathrm{FVa}, \mathrm{FVa}_{\text {Besançon }}$ has slightly ( $\leq 1.5$ fold) unfavorable kinetic parameters $\left(K_{m}, V_{\max }\right)$ of prothrombin activation, but also a lower rate of APC-catalyzed inactivation in the presence of protein $\mathrm{S}$.

Conclusions: $\mathrm{FV}_{\text {Besançon }}$ induces a hypercoagulable state via quantitative (markedly decreased FV level) and qualitative (phospholipid-binding defect) effects that affect anticoagulant pathways (anticoagulant activities of FV, FVa inactivation, tissue factor pathway inhibitor $\alpha$ level) more strongly than the prothrombinase activity of FVa. A possible specific role of platelet FV cannot be excluded.
\end{abstract}

KEYWORDS

factor $\mathrm{V}$, factor $\mathrm{V}$ deficiency, activated protein $\mathrm{C}$ resistance, phospholipids, venous thrombosis

Manuscript handled by: Alan Mast. 


\section{Essentials}

- FV has both pro- and anticoagulant functions; FV deficiency usually causes bleeding.

- We extensively phenotyped a FV-deficient patient with recurrent venous thrombosis.

- The patient was homozygous for FV Ala2086Asp ( $F V_{\text {Besançon }}$ ), a quanti-qualitative defect.

- $\mathrm{FV}_{\text {Besançon }}$ impacts anticoagulant pathways more strongly than prothrombinase.

\section{INTRODUCTION}

Coagulation factor $\mathrm{V}(\mathrm{FV})$ is a pivotal regulator of blood coagulation ${ }^{1}$ present in plasma (80\%) and platelets $(20 \%)^{2}$ Plasma FV, which circulates as a single-chain multidomain protein (A1-A2-B-A3-C1-C2), serves as a carrier of tissue factor pathway inhibitor (TFPI $\alpha$ ) in the circulation $^{3,4}$ and expresses anticoagulant activity as a cofactor of both TFPl $\alpha^{5-8}$ and activated protein C (APC), ${ }^{9,10}$ which also share the cofactor protein $\mathrm{S} .{ }^{11}$ Following proteolytic activation by $\mathrm{FXa}$ or thrombin, ${ }^{12} \mathrm{FV}$ is converted into a potent procoagulant cofactor (FVa) that assembles with FXa on negatively charged phospholipids to form the prothrombinase complex, thereby enhancing prothrombin activation by several orders of magnitude. ${ }^{13}$ Although TFPI $\alpha$ can inhibit partially activated forms of $F V,{ }^{14,15}$ fully activated $F V a$ is proteolytically inactivated by APC. Complete loss of FXa-cofactor activity requires APC-catalyzed cleavage at $\mathrm{Arg}^{306}$, but most FVa molecules are first cleaved at the kinetically favored $\mathrm{Arg}^{506}$ site, yielding a partially active intermediate that is subsequently fully inactivated via cleavage at $\mathrm{Arg}^{306}{ }^{16,17}$ Protein S enhances APC binding to negatively charged phospholipids ${ }^{18,19}$ and greatly stimulates FVa inactivation by accelerating both the $\mathrm{Arg}^{306}$ cleavage ${ }^{20,21}$ and (to a lesser extent) the $\operatorname{Arg}^{506}$ cleavage. ${ }^{21}$ Because FVa synergizes with protein $\mathrm{S}$ in localizing APC to the membrane surface, proper binding of FVa to phospholipids is paramount for efficient FVa inactivation. ${ }^{19}$

FV(a) binds to negatively charged phospholipids via two specific phosphatidylserine-binding sites located in the C1 and C2 domain, respectively. ${ }^{22,23}$ These domains have a $\beta$-barrel structure with three protruding loops ("spikes") that penetrate the membrane core, accommodating the phosphatidylserine head in the pocket among them. ${ }^{23,24}$

Platelet FV originates from the internalization and subsequent processing of plasma FV by bone marrow megakaryocytes ${ }^{25-27}$ and is stored in platelet $\alpha$-granules in (mostly) noncovalent complexes with multimerin 1 (MMRN1), ${ }^{28}$ which also binds to the $\mathrm{C} 1$ and $\mathrm{C} 2$ domains of $\mathrm{FV} .{ }^{29,30}$ Platelet $\mathrm{FV}$ is stored in a partially proteolysed form and is very resistant to APC-catalyzed inactivation. $^{31}$

Mutations in the F5 gene have been associated with both bleeding and thrombotic complications. Homozygosity or compound heterozygosity for loss-of-function mutations leading to FV deficiency is usually associated with a bleeding diathesis, whose severity is mainly determined by the residual platelet FV level. ${ }^{32}$ Differently, the common $\mathrm{FV}_{\text {Leiden }}$ mutation, ${ }^{33}$ which abolishes the $\mathrm{Arg}^{506}$ APC cleavage site in $\mathrm{FV}(\mathrm{a})$, results in plasma APC resistance and increased risk of venous thrombosis (VT). ${ }^{34}$ Besides $\mathrm{FV}_{\text {Leiden}}$, several other missense variants in FV have been associated with APC resistance and $\mathrm{VT}^{35-37}$ Here, we report and characterize a novel FV mutation (Ala2086Asp, $\mathrm{FV}_{\text {Besançon }}$ ), which is paradoxically associated with both FV deficiency and recurrent VT.

\section{MATERIALS AND METHODS}

\section{1 | Materials}

A list of all proteins, peptides, and lipids used in this study and their (commercial) sources is reported in the Supporting Information.

\subsection{Blood collection and workup}

After obtaining informed consent, blood was drawn from the patient in $3.2 \%$ sodium citrate and centrifuged at $150 \mathrm{~g}$ for $10 \mathrm{~min}$ to prepare platelet-rich plasma (PRP), which was adjusted to 150,000 platelets $/ \mu$ l with autologous platelet-poor plasma (PPP). PPP and adjusted PRP $\left(\mathrm{PRP}_{150}\right)$ were stored in aliquots at $-80^{\circ} \mathrm{C}$. Control PPP was prepared by pooling citrated plasma from 23 healthy volunteers (13 males and 10 females, mean age 34.7 years). Pooled PRP 150 from two healthy males (aged 38 and 49 years) was prepared and frozen as described above. PPP and PRP $_{150}$ were also obtained from a (30-year-old female) FV Leiden homozygote as an additional control. The study was approved by the Ethical Committee of Assistance Publique des Hôpitaux de Marseille and carried out according to the Helsinki Declaration. FV-depleted plasma was purchased from Siemens Healthcare (Marburg, Germany).

\section{3 | Thrombophilia screening and genetic analysis}

Thrombophilia screening included antithrombin, protein $C$ and protein S levels, FV Leiden and F2 20210G>A genotyping, as well as antiphospholipid antibodies screening.

The patient's genomic DNA was isolated from peripheral blood leukocytes. All 25 exons of the F5 gene were analyzed by Sanger sequencing. In addition, targeted resequencing of the following candidate genes for thrombosis was performed by next-generation sequencing: $A B O$ (blood group); F2 (prothrombin); F3 (tissue factor); F5, F7, F8, F10, F11, F12, F13A1, F13B (coagulation factors V, VII, VIII, X, $\mathrm{XI}, \mathrm{XII}$, and XIII); FGA, FGB, FGG (fibrinogen); SERPINC1 (antithrombin); PROC (protein C); and PROS1 (protein S). 


\subsection{Plasma levels of coagulation factors and inhibitors}

Plasma levels of prothrombin, FV, and total and free protein S were determined by in-house assays as previously described. ${ }^{3}$ The FVIII level was obtained from the Immunochrom APC resistance assay (Immuno, Vienna, Austria). Plasma full-length TFPI $\alpha$ was measured with an in-house ELISA. ${ }^{38}$

\section{5 | Thrombin generation}

Thrombin generation in PPP and PRP $_{150}$ was measured by calibrated automated thrombography ${ }^{39}$ using homemade tissue factor (TF) triggers. Coagulation was activated with 1 or $1.5 \mathrm{pM}$ TF in the presence of $40 \mu \mathrm{g} / \mathrm{ml}$ thermostable inhibitor of contact activation and in the absence and presence of $32 \mu \mathrm{g} / \mathrm{ml}$ anti-TFPI antibody cocktail (to evaluate the activity of the TFPI $\alpha$ system), ${ }^{38}$ or with $5 \mathrm{pM} \mathrm{TF}$ in the absence and presence of APC (to assess APC sensitivity). In some control experiments, thrombin generation in PRP was measured in the presence of anti-FV antibodies. The TF triggers for PPP were supplemented with vesicles prepared from synthetic phospholipids (DOPS/DOPC/DOPE, $20 / 60 / 20 \mathrm{M} / \mathrm{M} / \mathrm{M}$ ) or from a platelet membrane lipid extract (30 or $10 \mu \mathrm{M}$ final concentration). Fluorescence was read in a Fluoroskan Ascent reader (Thermo Labsystems), and thrombin generation curves were analyzed for lag time, peak height, and endogenous thrombin potential (ETP) using the dedicated software (Thrombinoscope). All calibrated automated thrombography assays were run in monoplo, but PRP experiments were repeated twice independently.

\subsection{Expression of recombinant FV}

The pMT2/FV expression plasmid containing the human full-length F5 cDNA was purchased from ATCC LGC Standards. The 6431C>A mutation (legacy nomenclature of Jenny et al. ${ }^{40}$ ) was introduced by site-directed mutagenesis and verified by sequencing (Proteogenix). HEK 293 cells (Griptite 293 MSR from ThermoFisher) were maintained in culture following the manufacturer's instructions and transiently transfected with PolyJet reagent (SignaGen Laboratories). Cells and conditioned media were harvested $72 \mathrm{~h}$ after transfection. Cells were lysed in RIPA buffer with cOmplete EDTA-free Protease Inhibitor Cocktail (Roche). For protein degradation inhibitor experiments, HEK 293 cells 48 h posttransfection were incubated with the proteasome inhibitor MG132 $(1 \mu \mathrm{M})$ or the lysosome inhibitor bafilomycin (30 nM). Cell lysates were harvested $24 \mathrm{~h}$ later and assayed for FV.

\section{7 | Immunoassays}

FV antigen levels were measured by ELISA (FV-EIA; Affinity Biologicals) according to the manufacturer's protocol. For immunoblots, identical volumes of conditioned medium or identical amounts of total protein were heat-denatured and reduced $\left(70^{\circ} \mathrm{C}\right.$; $10 \mathrm{~min}$ ), subjected to SDS-PAGE separation on $4 \%$ to $12 \%$ gradient NuPAGE gels (Life Technologies) and transferred to polyvinylidene fluoride membranes. Membranes were blocked for $1 \mathrm{~h}$ in Blotto blocking buffer (ThermoFisher) and incubated with a horseradish peroxidase (HRP)-conjugated anti-FV antibody (SAFV-HRP Affinity Biologicals, 1:1000 dilution), or a purified mouse anti-GAPDH antibody (Bio-Rad, 1:40,000 dilution) followed by HRP-conjugated secondary anti-mouse antibody (Bio-Rad, 1:20,000 dilution). Bands were visualized with enhanced chemiluminescent reagent and images were acquired using a chemiluminescence CCD imager (ImageQuant LAS 4000, GE Healthcare).

\section{8 $\quad$ Model system experiments}

Normal pooled plasma was prediluted in FV-depleted plasma (Siemens Healthcare) to the same FV concentration as in the pa-

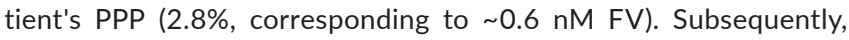
$2.8 \%$ normal PPP and the patient's PPP were diluted 500 -fold in $\mathrm{HN}$ buffer (25 mM Hepes, pH 7.7 at RT, $175 \mathrm{mM} \mathrm{NaCl}$ ) supplemented with $3 \mathrm{mM} \mathrm{CaCl}$ and $5 \mathrm{mg} / \mathrm{ml}$ bovine serum albumin (BSA). These dilutions were used as a source of normal $\mathrm{FV}$ and $\mathrm{FV}_{\text {Besançon }}$ in all model system experiments (i.e., phospholipid, FXa and prothrombin titrations of prothrombinase, FV activation and FVa inactivation time courses), which were performed essentially as reported. ${ }^{41} \mathrm{FV}$ activity was quantified by prothrombinase-based assays, as detailed in the Supporting Information and in the figure legends. Prothrombin activation was stopped after 1 to $5 \mathrm{~min}$ by subsampling to a buffer containing $50 \mathrm{mM}$ Tris (pH 7.9), $175 \mathrm{mM} \mathrm{NaCl}, 20 \mathrm{mM}$ EDTA, and $0.5 \mathrm{mg} / \mathrm{ml}$ ovalbumin, and the formed thrombin was quantified spectrophotometrically using the chromogenic substrate S-2238. The 500-fold diluted FV-depleted plasma was taken along as a blank in all experiments.

When PRP 150 instead of PPP was used as a source of FV, control $\mathrm{PRP}_{150}$ (pool of two healthy volunteers) was prediluted in FVdepleted plasma to the same FV concentration as in the patient's $\mathrm{PRP}_{150}$ (i.e., 3.4\%).

\subsection{APC-cofactor activity of FV}

The APC-cofactor activity of FV in the patient's PPP was determined twice in duplicate using the Immunochrom assay (Immuno), according to the manufacturer's instructions. This assay specifically quantifies the APC resistance arising from poor factor VIII(a) inactivation, where FV acts as a cofactor of the APC/protein S complex. ${ }^{42}$ The APCsr (ratio of the factor VIIla activities measured in the absence and presence of APC) decreases as APC resistance increases. Although the Immunochrom kit is not commercially available anymore, a similar assay based on commercial reagents has been described by Nogami et al. ${ }^{36}$ 


\subsection{Structural analysis}

The X-ray structure of the human FV C2 domain (PDB code 1CZT) was downloaded from Protein Data Bank. The three-dimensional structure of the human FV C1 domain was modelled with the SWISS-MODEL WebServer ${ }^{43}$ using the crystal structure of (inactivated) bovine FVa (PDB code 1SDD) as a template (81\% sequence identity). ${ }^{44}$ The wild-type FV C1 and C2 domains were in silico mutated to Trp1920Arg $\left(\mathrm{FV}_{\mathrm{Nara}}\right)^{36}$ and Ala2086Asp ( $\mathrm{FV}_{\text {Besançon }}$ ), respectively, and subjected to molecular dynamics simulations by applying standard force fields (AMBER14SB and TIP3P water model) and parameters (i.e., temperature at $300 \mathrm{~K}$, pressure at 1 bar, time step at 2 fs with SHAKE constraint) for 500 ns using Amber16 program.

\section{3 | RESULTS}

\section{1 | Case report}

A 37-year-old male, born to consanguineous parents (cousins) from Morocco, came to clinical attention because of recurrent VT (11 events). The first event was an unprovoked proximal deep vein thrombosis (DVT) of the left lower limb at the age of 19. This was followed by a proximal DVT of the left lower limb, two proximal DVTs of the right lower limb, and seven superficial vein thromboses. The last event, an extensive unprovoked DVT of the right lower limb (2013), was treated with low-molecular-weight heparin for 2 years because of the difficulty to maintain a stable prothrombin time-International Normalized Ratio. Afterwards, the patient was switched to apixaban ( $2.5 \mathrm{mg}$ twice daily). There was no family history of $\mathrm{VT}$, and thrombophilia screening returned only a heterozygous F2 20210G>A mutation. ${ }^{45}$ However, the patient's prolonged clotting times revealed a moderate FV deficiency (FV:C 3\%, FV:Ag 4\%) which had never manifested as a bleeding tendency. A homozygous mutation $(6431 \mathrm{C}>\mathrm{A})$ predicting an amino acid substitution in the C2 domain of FV (Ala2086Asp, $\mathrm{FV}_{\text {Besançon }}$ ) [nucleotide and amino acid numbering according to the legacy nomenclature of Jenny et al., ${ }^{40}$ ] was identified by F5 gene sequencing. Targeted resequencing of 17 candidate genes for thrombosis, including all coagulation factors and the main coagulation inhibitors, disclosed only one heterozygous variant ( $r$ 17549671) in the F13B gene (B-subunit of factor XIII), which was scored as "benign" by PolyPhen and "neutral" by Mutation Taster. The patient's mother and one of her daughters have FV:C levels of $50 \%$, but their DNA was not available for study.

Coagulation factor and inhibitor levels in the patient's plasma (collected when the patient was not on anticoagulant therapy) are reported in Table 1. As expected for an FV-deficient patient, ${ }^{3}$ TFPI $\alpha$ levels were also markedly decreased.

\subsection{Thrombin generation in PPP and PRP}

To assess the patient's coagulation potential, thrombin generation at low TF in the absence and presence of anti-TFPI antibodies and at
TABLE 1 Levels of coagulation factors and inhibitors in the patient's plasma

\begin{tabular}{|c|c|c|}
\hline Coagulation Protein & Level in PPP, \% & Level in $\mathrm{PRP}_{150}, \%$ \\
\hline Prothrombin & 101.4 & 102.4 \\
\hline Factor $\mathrm{V}^{*}$ & 2.8 & 3.4 \\
\hline Factor VIII & 143.0 & ND \\
\hline Total protein S & 92.6 & 94.5 \\
\hline Free protein $\mathrm{S}$ & 91.6 & ND \\
\hline Full-length TFPI $\alpha$ & 24.1 & 49.4 \\
\hline
\end{tabular}

All levels are expressed as percentage of normal pooled plasma (for $\mathrm{PPP}$ ) or of a pool of $\mathrm{PRP}_{150}$ from two healthy males (for $\mathrm{PRP}_{150}$ ). Abbreviations: FV, factor V; ND, not determined; PRP $_{150}$, PRP adjusted to 150,000 platelets $/ \mu$ and frozen.

${ }^{*} \mathrm{FV}$ levels (in bold) were measured with a prothrombinase-based assay at saturating FXa and phospholipid concentrations.

higher TF in the presence of increasing concentrations of APC was measured in both PPP (Figure 1) and $\mathrm{PRP}_{150}$ (frozen after normalizing the platelet count to 150,000 platelets/ $\mu$; Figures 2 and 3).

Control PPP (Figure 1A) showed a normal thrombin generation at $1.5 \mathrm{pM}$ TF (lag time $9.6 \mathrm{~min}$, peak height $53.6 \mathrm{nM}$ ) and a typical procoagulant response to the addition of anti-TFPI antibodies (lag time $4.2 \mathrm{~min}$, peak height $220.8 \mathrm{nM}$ ), with a TFPI ratio ${ }^{38}$ of 0.24 . Differently, the patient's PPP (Figure 1B) showed a markedly prolonged lag time (30.5 min) and a low peak height (30.8 nM), suggestive of a hypocoagulable state in line with the patient's very low FV level. Blocking TFPI in the patient's PPP shortened the lag time (19.7 $\mathrm{min}$ ) and increased the peak height (79.3 nM) of thrombin generation, but not as much as in control PPP. The patient's TFPI ratio was 0.39 , indicating a partial impairment of the TFPI $\alpha$ system, attributable to the low levels of TFPI $\alpha$ and its cofactor FV, whereas protein $\mathrm{S}$ levels were normal (Table 1 ). Similar results were obtained at 5 pM TF (Figure 1C,D). In the absence of APC, thrombin generation in the patient's PPP was considerably delayed (lag time $12.3 \mathrm{~min}$ vs. $3.3 \mathrm{~min}$ ) and showed a lower peak height than in control PPP (72 nM vs. $128 \mathrm{nM}$ ). However, the patient's anticoagulant response to APC was also decreased (Figure 1F), although not as much as in FV Leiden homozygous plasma (Figure 1E). Thrombin generation in the patient's PPP could not be mimicked by diluting control PPP to $2.8 \%$ in FV-depleted plasma, but was strikingly similar to that of FV-depleted plasma reconstituted with $2.8 \%$ FV1 (Figure S1), a glycosylation isoform of FV with reduced phospholipid binding affinity, ${ }^{46}$ suggesting that the low thrombin generation in the patient's PPP is not due to the low FV level, but rather to impaired binding of $F V_{\text {Besançon }}$ to phospholipids (see the following section).

In the patient's PRP $_{150}$, thrombin generation at $1 \mathrm{pM}$ TF was much higher than in control $\mathrm{PRP}_{150}$ (peak height $131.7 \mathrm{nM}$ vs. $40.9 \mathrm{nM}$ ) and hardly sensitive to the addition of anti-TFPI antibodies (TFPI ratio 0.86 vs. 0.32 ), indicating an almost complete abolition of TFPl $\alpha$ activity (Figure $2 \mathrm{~A}, \mathrm{~B}$ ). To exclude the presence of a procoagulant component in the patient's platelets, thrombin generation was 
A

Control PPP, 1.5 pM TF

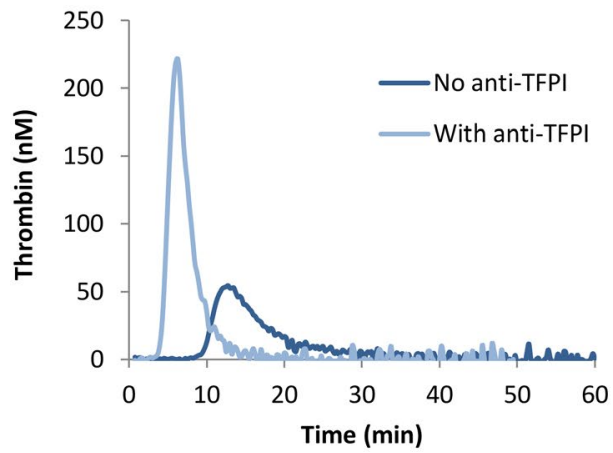

C

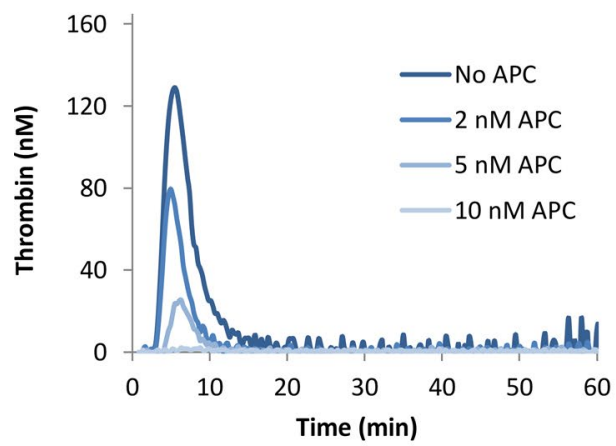

E FV Leiden homozygous PPP, 5 pM TF

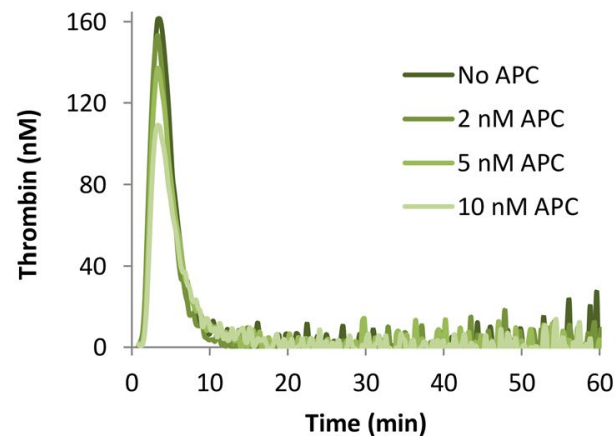

B

Patient PPP, 1.5 pM TF

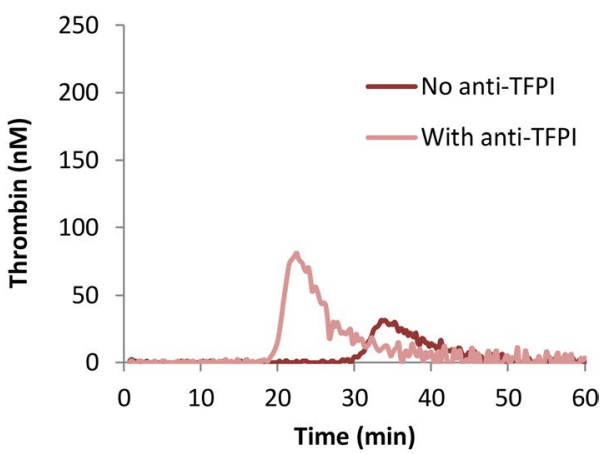

D

Patient PPP, 5 pM TF

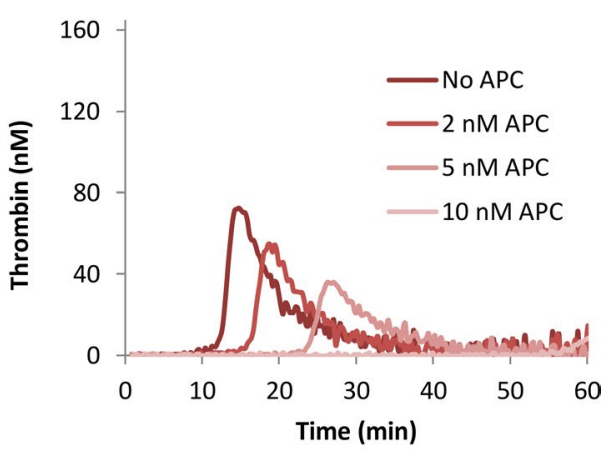

$\mathbf{F}$

Residual ETP

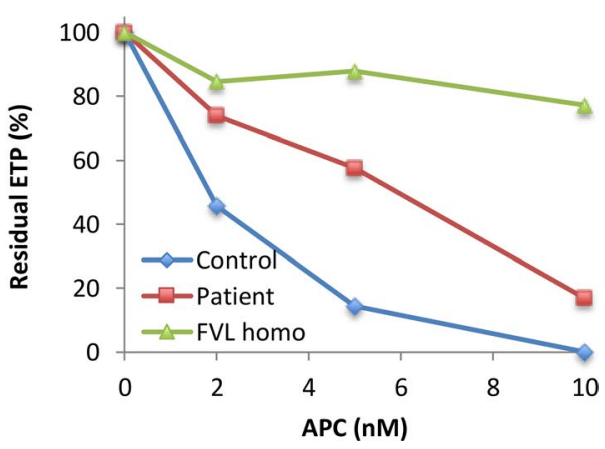

FIGURE 1 Thrombin generation in PPP. Thrombin generation in (A) normal pooled plasma (control PPP) and (B) patient's PPP was measured after initiating coagulation with $1.5 \mathrm{pM}$ TF and $30 \mu \mathrm{M}$ 20/60/20 DOPS/DOPC/DOPE phospholipid vesicles in the absence and presence of anti-TFPI antibodies. Thrombin generation in (C) control PPP, (D) patient's PPP, and (E) FV Leiden homozygous PPP was measured after initiating coagulation with $5 \mathrm{pM}$ TF and $10 \mu \mathrm{M}$ 20/60/20 DOPS/DOPC/DOPE phospholipid vesicles in the presence of 0 to $10 \mathrm{nM}$ APC. (F) The residual ETP was plotted as a function of APC concentration. ETP, endogenous thrombin potential; PPP, platelet-poor plasma; TF, tissue factor; TFPI, tissue factor pathway inhibitor.

also measured in a mixture of $25 \%$ patient PRP and $75 \%$ control PRP. This $25 / 75$ PRP mix contains hardly any $\mathrm{FV}_{\text {Besançon }}$ but $25 \%$ of the patient's "platelet background," while retaining almost normal levels of FV (76\%) and TFPI (87\%). Thrombin generation in the $25 / 75$ PRP mix was almost identical to that of control PRP (Figure 2C), suggesting that the patient's platelet background by itself does not enhance thrombin generation. Moreover, thrombin generation in the patient's PRP (but not in control PRP) could be completely inhibited by an anti-FV antibody (Figure 2D,E), confirming its dependence on (platelet) $\mathrm{FV}_{\text {Besançon }}$
At $5 \mathrm{pM}$ TF, thrombin generation in the patient's PRP $_{150}$ was only slightly delayed (6.5 $\mathrm{min}$ vs. $2.5 \mathrm{~min}$ ) and again reached a higher peak height (176.4 nM vs. $105.9 \mathrm{nM}$ ) than in control $\mathrm{PRP}_{150}$ (Figure 3A,B). Moreover, the patient's PRP $_{150}$ was extremely APC resistant, with a residual ETP of $68 \%$ at $50 \mathrm{nM}$ APC versus only $7.5 \%$ in control PRP 150 (Figure 3E). In fact, the APC resistance of the patient's $\mathrm{PRP}_{150}$ approached that of FV Leiden homozygous $\mathrm{PRP}_{150}$ (Figure 3D,E), whereas the 25/75 PRP mix had a normal APC sensitivity (Figure 3C,E), excluding the presence of an APC and/or protein $\mathrm{S}$ inhibitor in the patient's platelets. 

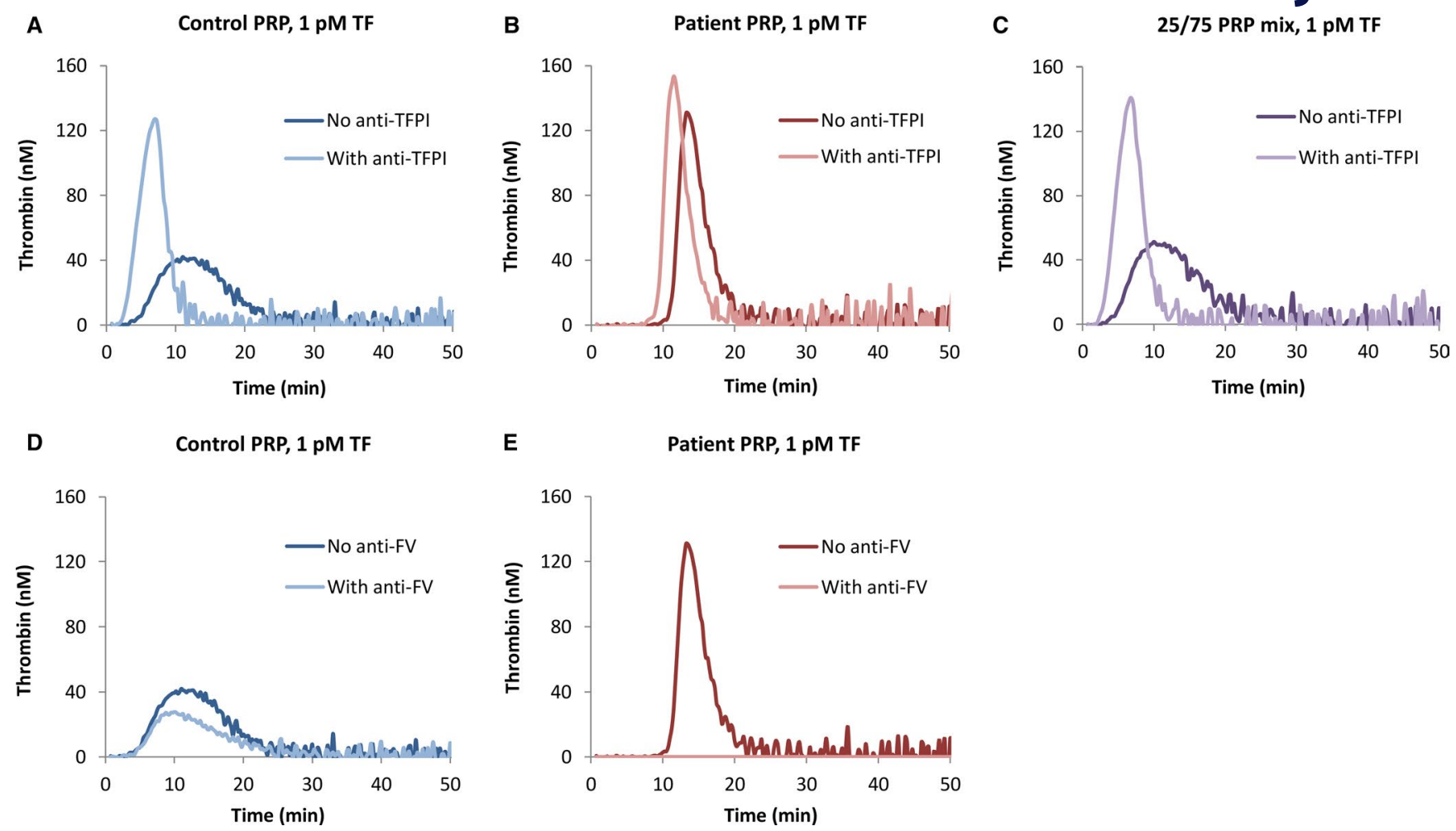

FIGURE 2 Thrombin generation at low TF in $\mathrm{PRP}_{150}$. Thrombin generation in (A,D) pooled $\mathrm{PRP}_{150}$ of two healthy males (control PRP 150 ), $(B, E)$ patient's $\mathrm{PRP}_{150}$, and (C) a 25\%/75\% mixture of patient's and control $\mathrm{PRP}_{150}$ was measured after initiating coagulation with $1 \mathrm{pM}$ TF in the absence and presence of (A-C) anti-TFPI antibodies or (D,E) anti-FV antibodies. TF, tissue factor; $\mathrm{PRP}_{150}$, adjusted platelet-rich plasma.

Thus, in contrast to PPP, the patient's PRP $_{150}$ revealed a hypercoagulable state in line with the clinical phenotype and despite an FV level of only $3.4 \%$ (Table 1 ).

Control experiments performed with PRP from a normal donor indicated that frozen/thawed $\mathrm{PRP}_{150}$ (as used here for both patient and controls) yields shorter lag times and higher peak heights/ETPs, but less APC resistance than the corresponding fresh $\mathrm{PRP}_{150}$ stimulated with collagen (not shown).

\subsection{In silico analysis of $\mathrm{FV}_{\text {Besançon }}$}

The patient was homozygous for a mutation predicting the Ala2086Asp substitution in the $\mathrm{C} 2$ domain of $\mathrm{FV}$ ( $\left.F V_{\text {Besançon }}\right)$. Ala ${ }^{2086}$ is evolutionarily conserved from zebrafish to human, suggesting that other residues are hardly tolerated at this position. Accordingly, the Ala2086Asp substitution was rated as "probably damaging" by PolyPhen $2,{ }^{47}$ whereas SIFT ${ }^{48}$ predicted that it "may affect protein function."

The FV C2 domain is involved in FV(a) binding to negatively charged phospholipids. As revealed by the crystal structure, ${ }^{24}$ this domain has three flexible loops that, in the so-called "open conformation," penetrate the phospholipid bilayer and anchor FV(a) to the membrane, whereas the polar head of phosphatidylserine is accommodated in the groove formed by these spikes (Figure 4A). To evaluate whether the Ala2086Asp substitution influences the structural conformation of the FV C2 domain, molecular dynamics simulations of the wild-type and mutant FV C2 domains were performed (Figure 4B-D). This analysis suggested that replacing $\mathrm{Ala}^{2086}$ by an Asp residue makes spike 1 more rigid, thereby reducing the average distance between spikes 1 and 3 . These changes would favor a more "closed conformation" of the spikes, thereby potentially hindering the interaction of the mutant FV C2 domain with phosphatidylserine.

\subsection{Expression of recombinant $\mathrm{FV}_{\text {Besançon }}$}

Recombinant wild-type $\mathrm{FV}$ and $\mathrm{FV}_{\text {Besançon }}$ were expressed in HEK 293 cells and FV levels were measured $72 \mathrm{~h}$ posttransfection (Figure S2A). The FV antigen level in conditioned media was $47.9 \pm 8.0 \mathrm{ng} / \mathrm{ml}$ for wild-type FV, but undetectable for $\mathrm{FV}_{\text {Besançon. }}$. Using a highly sensitive prothrombinase-based activity assay, $\mathrm{FV}_{\text {Besançon }}$ in the media was quantified as a mere $3.8 \pm 0.5 \mathrm{pM}$ vs. $180.9 \pm 16.6$ pM wild-type FV (relative expression: $2.1 \%$ ). In the corresponding cell lysates, $\mathrm{FV}_{\text {Besançon }}$ antigen $(6.5 \pm 2.2 \mathrm{ng} / \mathrm{ml})$ was $\sim 15 \%$ of the wild-type FV antigen $(44.7 \pm 15.8 \mathrm{ng} / \mathrm{ml})$. Western blot analysis confirmed the absence of $\mathrm{FV}_{\text {Besançon }}$ in conditioned media and its retention in the cell lysates (Figure S2B). In fact, the proportion of $\mathrm{FV}_{\text {Besançon }}$ retained in the cell lysates appeared to be higher than wild-type FV when assessed by Western blot, suggesting that $\mathrm{FV}_{\text {Besançon }}$ was not optimally recognized in the ELISA. Overall, these data suggest that the Ala2086Asp mutation produces a misfolded 
A

Control PRP, 5 pM TF

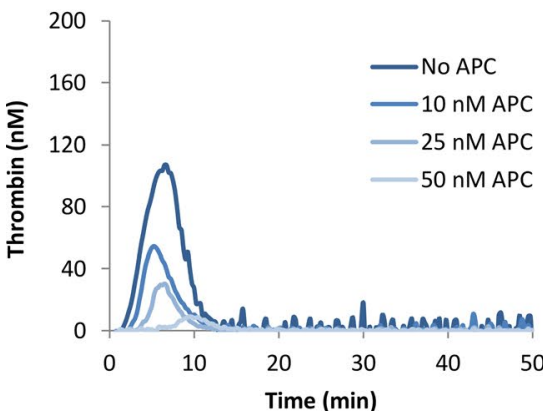

D FV Leiden homozygous PRP, 5 pM TF

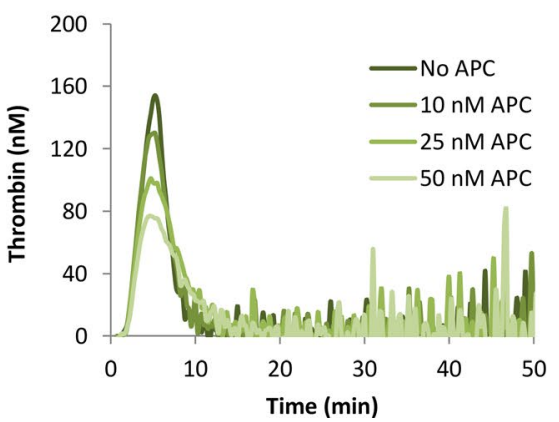

B

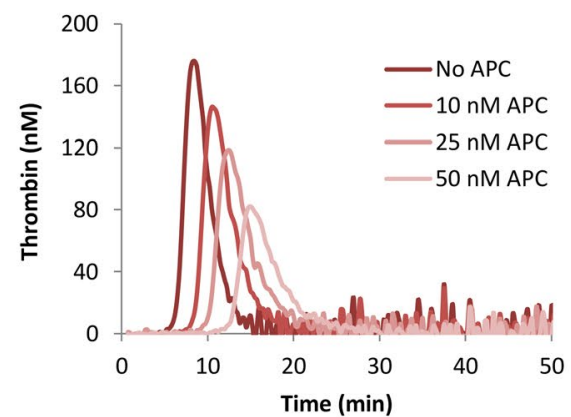

$\mathbf{E}$

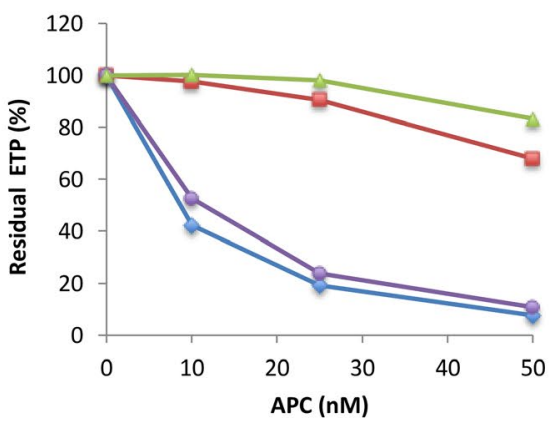

C

25/75 PRP mix, 5 pM TF

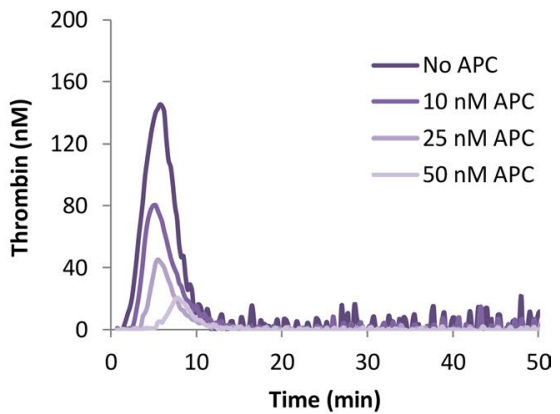

$\sim$ Control PRP

$\neg$ Patient PRP

$\multimap 25 / 75$ PRP mix

$\rightarrow$ FVL homo PRP

FIG URE 3 APC titrations of thrombin generation in $\mathrm{PRP}_{150}$. Thrombin generation in (A) pooled PRP 150 of two healthy males (control PRP $_{150}$ ), (B) patient's PRP 150 , (C) a 25\%/75\% mixture of patient's and control PRP ${ }_{150}$, and (D) FV Leiden homozygous PRP 150 was measured after initiating coagulation with $5 \mathrm{pM}$ TF in the presence of 0 to $50 \mathrm{nM}$ APC. (E) The residual ETP was plotted as a function of APC concentration. APC, activated protein C; ETP, endogenous thrombin potential; FV, factor V; PRP 150 , adjusted platelet-rich plasma; TF, tissue factor.

FV protein that is hardly secreted, accounting for the FV deficiency observed in the patient. Neither the proteasome inhibitor MG132 nor the lysosome inhibitor bafilomycin could restore secretion of $\mathrm{FV}_{\text {Besançon }}$ in conditioned media (not shown).

Because of the extremely low expression of recombinant $\mathrm{FV}_{\text {Besançon }}$, highly diluted patient's plasma was used as a source of $\mathrm{FV}_{\text {Besançon }}$ for all functional characterization experiments.

\section{5 | Phospholipid-binding properties of $\mathrm{FV}(\mathrm{a})_{\text {Besançon }}$}

To test the phospholipid-binding properties of $\mathrm{FV}(\mathrm{a})_{\text {Besançon }}$, we performed phospholipid titrations of prothrombinase activity using DOPS/DOPC vesicles with $5 \%, 10 \%$, or $20 \%$ phosphatidylserine. As shown in Figure 5, the prothrombinase rates of both normal FVa and $\mathrm{FVa}_{\text {Besançon }}$ progressively increased with the phosphatidylserine content of the vesicles and, for each type of vesicle, with the phospholipid concentration. However, the highest concentrations of the vesicles containing $20 \%$ phosphatidylserine showed an inhibitory effect, probably because of the "dilution" of the reactants on the phospholipid surface. Under all conditions, $\mathrm{FVa}_{\text {Besançon }}$ supported lower prothrombinase activity than normal FVa. Although the maximal prothrombinase rates of both FVa variants were similar on all three types of vesicle, the phospholipid concentration required to achieve the half-maximal rate was up to 6-fold higher for $\mathrm{FVa}_{\text {Besançon }}$ than for normal $\mathrm{FVa}$, supporting the in silico prediction that $\mathrm{FV}_{\text {Besancon }}$ has lower affinity for phospholipids. However, we could not prove this directly in a solid-phase phosphatidylserine binding assay ${ }^{22,36}$ using control and patient's PPP as a source of FV (data not shown).

\subsection{Activation and prothrombinase activity of $\mathrm{FV}_{\text {Besançon }}$}

$\mathrm{FV}_{\text {Besançon }}$ was activated by thrombin similarly to normal FV (Figure 6A). The second-order rate constant of $\mathrm{FV}$ activation was $3.3 \times 10^{6} \mathrm{M}^{-1} \mathrm{~s}^{-1}$ for normal FV and $4.6 \times 10^{6} \mathrm{M}^{-1} \mathrm{~s}^{-1}$ for $\mathrm{FV}_{\text {Besançon }}$ (Table S1).

In an FXa titration of prothrombinase at suboptimal phospholipid concentration (Figure 6B), $\mathrm{FVa}_{\text {Besançon }}$ had 2-fold lower affinity for FXa than normal FVa $\left(K_{d} 3.9 \mathrm{nM}\right.$ vs. $\left.1.8 \mathrm{nM}\right)$ and reached a lower maximal prothrombinase rate $(1.2 \mathrm{nM} \mathrm{Ila/min} \mathrm{vs.} 3.1 \mathrm{nM} \mathrm{Ila/min}$; Table S1).

Also, a prothrombin titration (Figure 6C) showed that prothrombinase complexes containing $\mathrm{FVa}_{\text {Besançon }}$ have somewhat higher Michaelis menten constant for prothrombin ( $0.53 \mathrm{nM}$ vs. $0.35 \mathrm{nM})$ and reach a slightly lower maximum velocity $(4.4 \mathrm{nM} \mathrm{Ila} / \mathrm{min}$ vs. $5.4 \mathrm{nM} \mathrm{Ila} /$ $\mathrm{min}$ ) than prothrombinase complexes containing normal FVa (Table S1). Overall, these data suggest a slight impairment of prothrombinase 


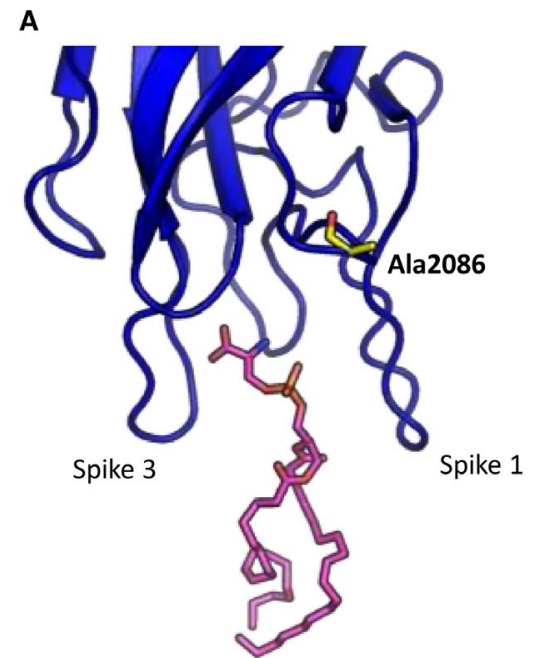

B

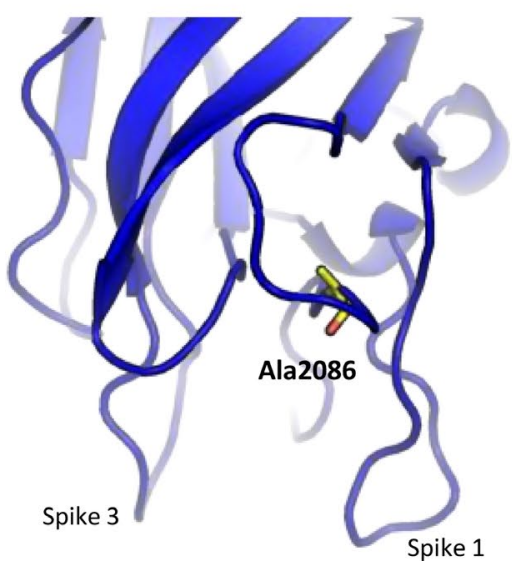

C

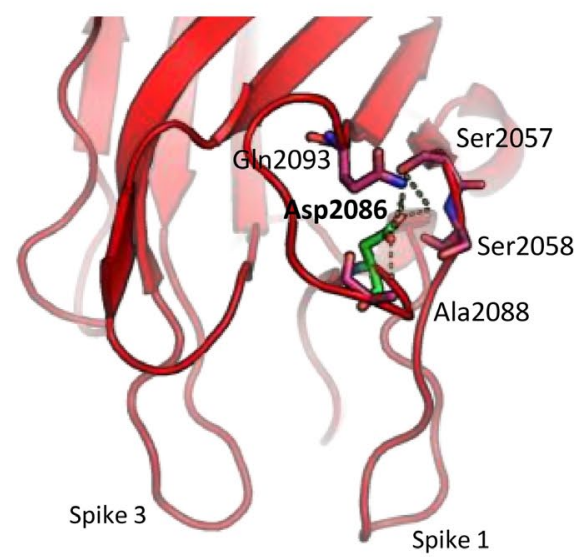

D

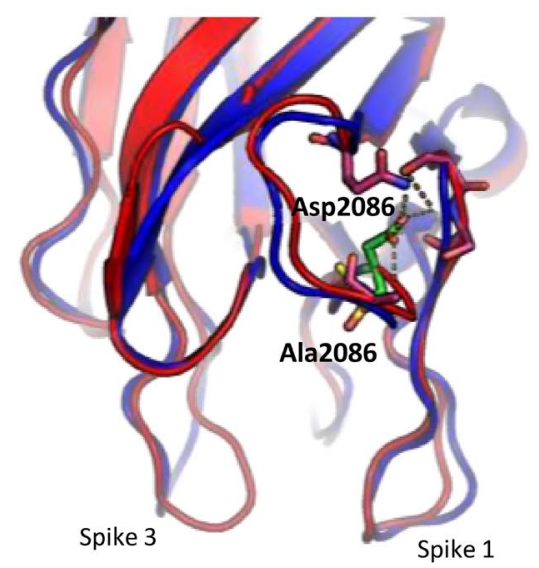

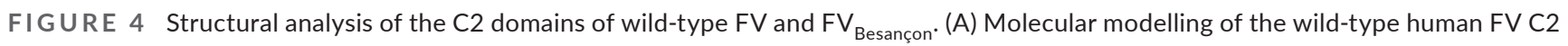
domain (blue) in complex with the phospholipid DOPS (magenta), based on the X-ray structure of the human C2 domain by Macedo-Ribeiro et al (PDB code 1CZT). ${ }^{24}$ (B) Structure of the wild-type FV C2 domain obtained after 500 ns of MD simulation: the position of Ala2086 is shown. (C) Structure of the $F V_{\text {Besançon }}$ C2 domain after 500 ns of MD simulation: Ala2086 is replaced by Asp, which forms hydrogen bonds (yellow dashes) with neighboring residues that stabilize spike 1, thereby reducing its distance from spike 3. (D) Comparison between the wild-type (blue) and mutant (red) FV C2 domains. FV, factor V; MD, molecular dynamics.

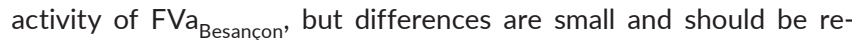
garded with caution because of the extremely low FVa ( 1 pM) in the assay and possible influences of the plasma background.

\subsection{Inactivation of $\mathrm{FVa}_{\text {Besançon }}$ by $\mathrm{APC} \pm$ protein $\mathrm{S}$}

The time-courses of normal $\mathrm{FVa}$ and $\mathrm{FVa}_{\text {Besançon }}$ inactivation by APC in the absence and presence of protein S on 10/90 DOPS/DOPC lipids are shown in Figure 7A-D, and the corresponding rate constants of $\mathrm{Arg}^{506}$ and $\mathrm{Arg}^{306}$ cleavage are reported in Table S2. As expected, ${ }^{16,17}$ the APC-catalyzed inactivation of normal FVa (Figure 7A) showed an initial rapid phase (corresponding to cleavage at $\mathrm{Arg}^{506}$ ), causing the loss of $\sim 50 \%$ of the original FVa activity, followed by a slower phase (corresponding to cleavage at $\mathrm{Arg}^{306}$ ). The addition of protein $\mathrm{S}$ resulted in a 2-fold enhancement of the $\mathrm{Arg}^{506}$ cleavage and a 16fold enhancement of the $\mathrm{Arg}^{306}$ cleavage, considerably accelerating
FVa inactivation, in line with earlier reports. ${ }^{20,21}$ The APC-mediated inactivation of $\mathrm{FVa}_{\text {Besançon }}$ (Figure $7 \mathrm{~B}$ ) showed an analogous biphasic pattern, with kinetic parameters similar to those of normal FVa (Table S2). However, the effect of protein $\mathrm{S}$ on $\mathrm{FVa}_{\text {Besançon }}$ inactivation was less pronounced than in normal FVa, especially for the $\mathrm{Arg}^{306}$ cleavage, which was stimulated only 2.5 times in $\mathrm{FVa}_{\text {Besançon }}$ versus 16 times in normal FVa (Table S2). Hence, although the curves of normal $\mathrm{FVa}$ and $\mathrm{FVa}_{\text {Besançon }}$ inactivation in the absence of protein $\mathrm{S}$ were similar (Figure $7 \mathrm{C}$ ), in the presence of protein $\mathrm{S}, \mathrm{FVa}_{\text {Besançon }}$ was less readily inactivated than normal FVa (Figure 7D).

Essentially, the same results were obtained when FVa inactivation was followed on platelet lipids (Figure 7E-H and Table S2), but the difference between normal $\mathrm{FVa}$ and $\mathrm{FVa}_{\text {Besançon }}$ was more pronounced, especially in the presence of protein $\mathrm{S}$.

However, because of the limitations of using diluted plasma as a source of $F V(a)$, the observed differences between normal FVa and $\mathrm{FVa}_{\text {Besançon }}$ should be interpreted with caution. 
A

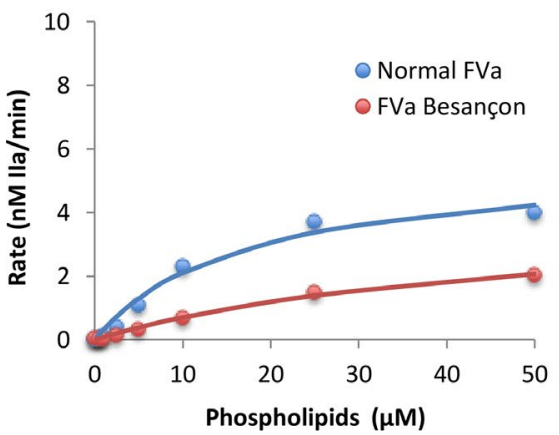

B

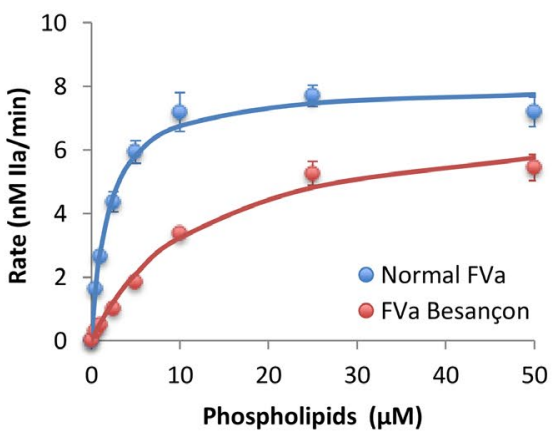

C

20/80 DOPS/DOPC

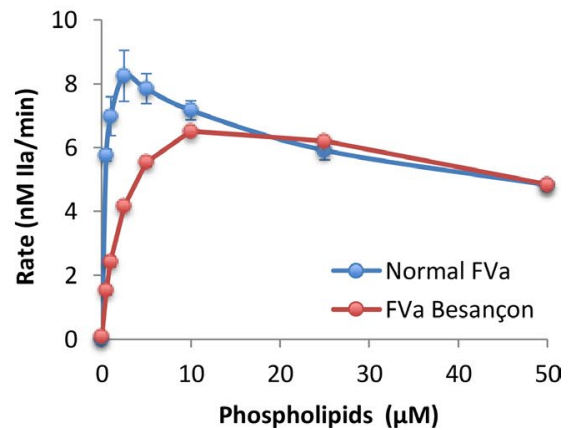

FIGURE 5 Phospholipid-titrations of prothrombinase with normal FV(a) and FV(a) Besançon. Plasma containing $2.8 \%$ normal FV or FV Besançon was diluted 500 -fold in $\mathrm{HN}$ buffer supplemented with $3 \mathrm{mM} \mathrm{CaCl}$ and $5 \mathrm{mg} / \mathrm{ml} \mathrm{BSA}$. After full activation of FV, prothrombinase activity was determined at limiting FVa concentration ( 1 pM), $0.3 \mathrm{nM} F X a$ and $0.5 \mu \mathrm{M}$ prothrombin on (A) 0 to $50 \mu \mathrm{M}$ 5/95 DOPS/DOPC vesicles, (B) 10/90 DOPS/ DOPC vesicles, or (C) 20/80 DOPS/DOPC vesicles. Data, representing the mean of two independent experiments, were fitted to the equation of a rectangular hyperbola (except in panel $\mathrm{C}$ ). The half-maximal rate $\left(\mathrm{K}_{1 / 2}\right)$ of normal $\mathrm{FVa}$ and $\mathrm{FVa} \mathrm{B}_{\text {Besancon }}$ obtained from the fits were $17.1 \mu \mathrm{M}$ and $48.7 \mu \mathrm{M}$ for 5/95 DOPS/DOPC vesicles and 1.9 $\mu \mathrm{M}$ and $12.1 \mu \mathrm{M}$ for 10/90 DOPS/DOPC vesicles. BSA, bovine serum albumin; FV, factor V.

A

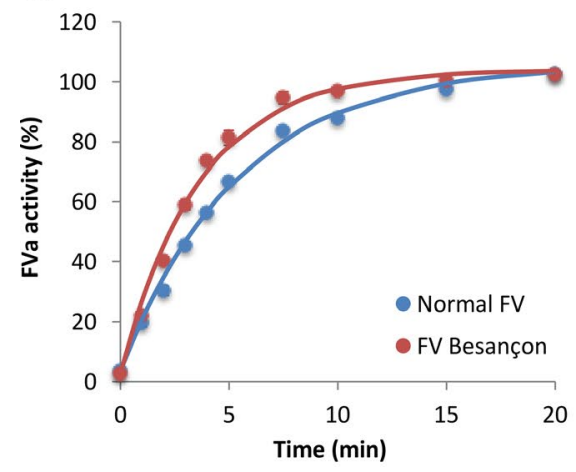

B

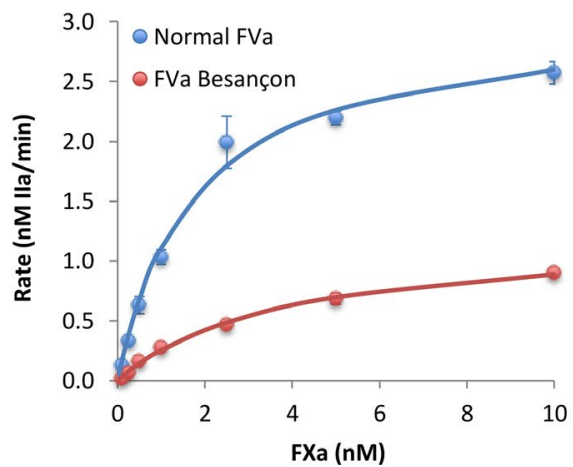

C

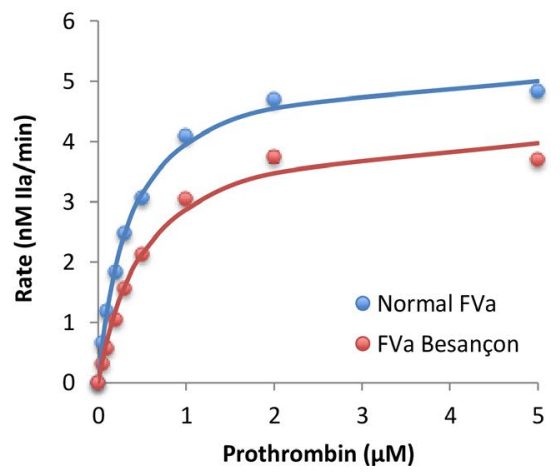

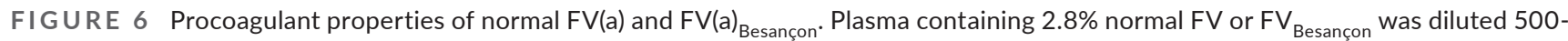
fold in $\mathrm{HN}$ buffer supplemented with $3 \mathrm{mM} \mathrm{CaCl}_{2}$ and $5 \mathrm{mg} / \mathrm{ml} \mathrm{BSA}$. (A) Time course of activation of normal $\mathrm{FV}_{\text {and }} \mathrm{FV}_{\mathrm{Besançon}}$. Plasma $\mathrm{FV}$ was activated with $1 \mathrm{nM}$ thrombin and FVa activity was quantified at regular time points in a prothrombinase-based assay containing $1 \mathrm{nM} F X a, 0.5 \mu \mathrm{M}$ prothrombin, $36 \mu \mathrm{M}$ phospholipid vesicles, and $1 \mu \mathrm{M}$ Pefabloc-TH. (B) FXa/FVa complex formation. After full activation of plasma FV, prothrombinase activity was determined at limiting FVa concentration ( 0.7 pM), varying FXa concentration (0-10 nM), and $1 \mu \mathrm{M}$ prothrombin on $2 \mu \mathrm{M}$ 5/95 DOPS/DOPC vesicles. (C) Prothrombin titration of prothrombinase. After full activation of plasma FV, prothrombinase activity was determined at limiting FVa concentration ( 0.7 pM), $4 \mathrm{nM} \mathrm{FXa} \mathrm{and} \mathrm{varying} \mathrm{prothrombin} \mathrm{concentration} \mathrm{(0.05-}$ $5 \mu \mathrm{M})$ on $20 \mu \mathrm{M}$ 5/95 DOPS/DOPC vesicles. Each curve represents the mean of two independent experiments. Kinetic parameters obtained by fitting the data are reported in Table S1. BSA, bovine serum albumin; FV, factor V.

\subsection{APC-cofactor activity of $\mathrm{FV}_{\text {Besançon }}$}

The Immunochrom APCsr of the patient's plasma was $1.44 \pm 0.04$ versus $2.04 \pm 0.001$ in normal pooled plasma. The patient's APCsr was even lower than that of FV-depleted plasma $(1.55 \pm 0.01)$ and FV $_{\text {Leiden }}$ homozygous plasma (1.63 \pm 0.04 ), suggesting that the patient's plasma contains no APC cofactor activity at all. This is probably the result of the very low $\mathrm{FV}$ level and phospholipid-binding defect of $\mathrm{FV}_{\text {Besançon. }}$.

\section{9 | Possible role of platelet FV}

The higher thrombin generation and extreme APC resistance observed in the patient's PRP $_{150}$ compared with control PRP $_{150}$ could not be mimicked by measuring thrombin generation in PPP on phospholipid vesicles prepared from platelet lipids (Figure S3).

Because platelet FV is structurally and functionally different from plasma $\mathrm{FV},{ }^{27}$ we repeated the $\mathrm{FXa}$ and prothrombin titrations

FIGURE 7 Inactivation of normal $F V a$ and $\mathrm{FVa}_{\text {Besançon }}$ by $\mathrm{APC} \pm$ protein $\mathrm{S}$. Plasma containing $2.8 \%$ normal $\mathrm{FV}$ or $\mathrm{FV}$ Besançon was diluted 500 -fold in $\mathrm{HN}$ buffer supplemented with $3 \mathrm{mM} \mathrm{CaCl}$ and $5 \mathrm{mg} / \mathrm{ml} \mathrm{BSA}$. After full activation of FV, FVa inactivation by $0.24 \mathrm{nM}$ $A P C \pm 200 \mathrm{nM}$ protein $\mathrm{S}$ in the presence of (A-D) $40 \mu \mathrm{M}$ 10/90 DOPS/DOPC lipids and by $0.24 \mathrm{nM}$ APC $\pm 100 \mathrm{nM}$ protein $\mathrm{S}$ in the presence of $(\mathrm{E}-\mathrm{H}) 10 \mu \mathrm{M}$ platelet lipids was followed by regular subsampling to a prothrombinase-based assay containing $5 \mathrm{nM} F X a$ and $0.5 \mu \mathrm{M}$ prothrombin. FVa activity was expressed as percentage of the maximal FVa activity achieved before adding APC \pm protein $\mathrm{S}$. The data, representing the mean of (A-D) three or $(\mathrm{E}-\mathrm{H})$ two independent experiments, were fitted with a random biphasic model. ${ }^{17} \mathrm{Kinetic}$ parameters are reported in Table S2. APC, activated protein C; BSA, bovine serum albumin; FV, factor V. 

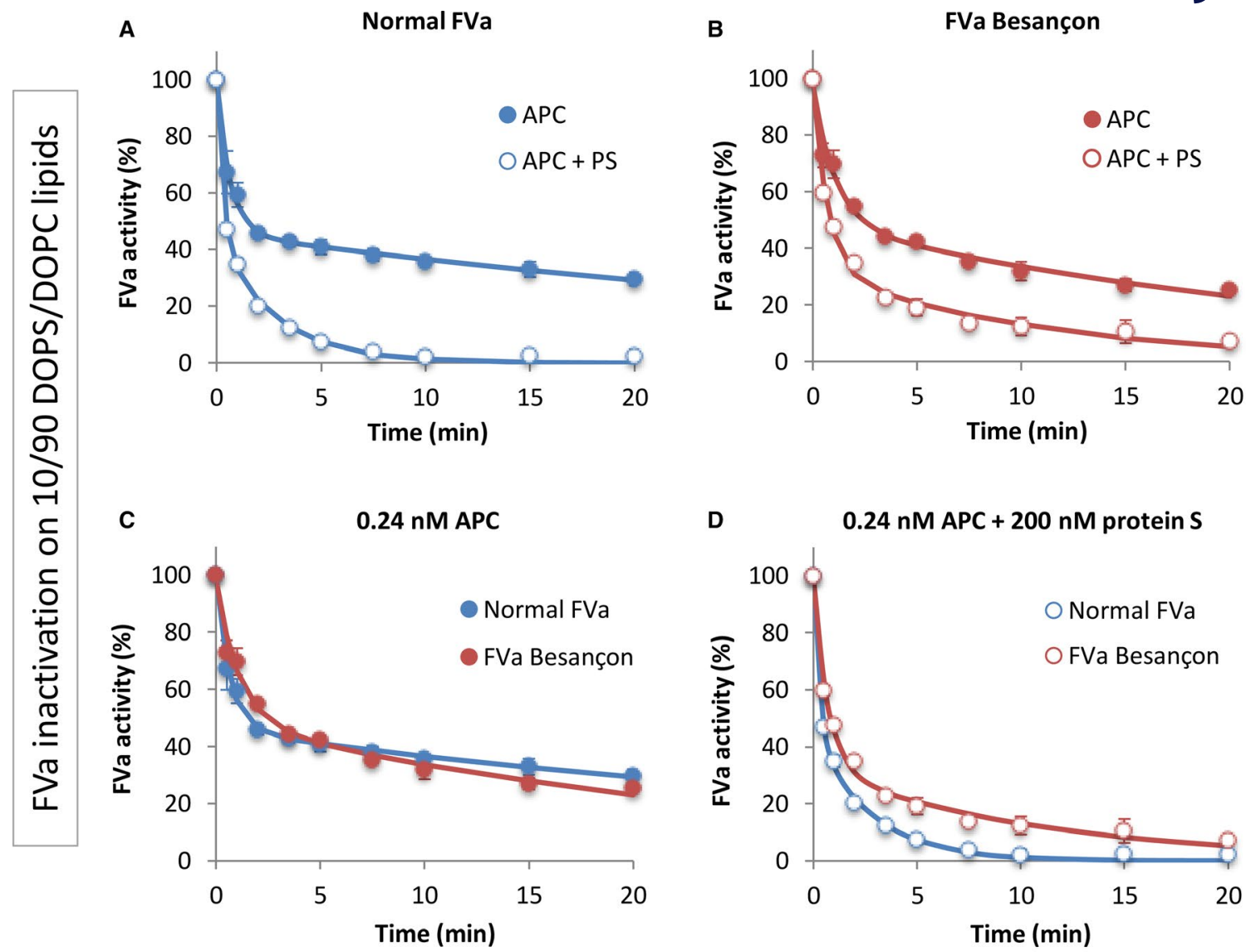

E

Normal FVa

F

FVa Besançon
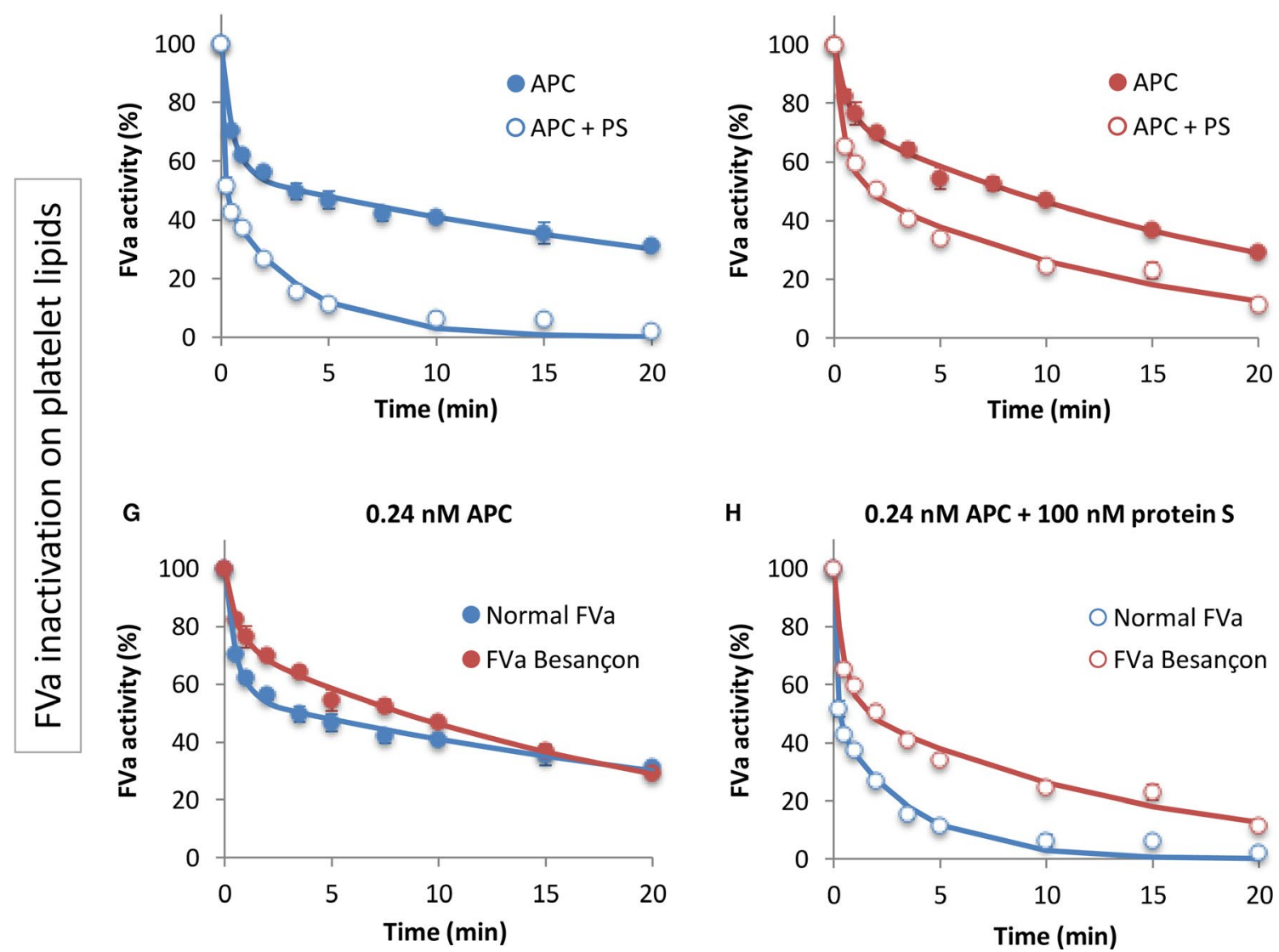
of prothrombinase using highly diluted control and patient's $\mathrm{PRP}_{150}$ as a source of (platelet) FV (Figure S4). Overall, results were similar to those obtained with PPP, but the $\mathrm{K}_{d}$ of $\mathrm{FVa}_{\text {Besançon }}$ for FXa was 4-fold lower in $\mathrm{PRP}_{150}$ than in PPP (Table S1).

Finally, because the platelet FV carrier MMRN1 has been shown to bind to the FV C2 domain ${ }^{29}$ and to inhibit thrombin generation, ${ }^{49}$ we also determined the effect of exogenously added MMRN1 on FV activation and prothrombinase activity in model systems using highly diluted patient's and control PRP ${ }_{150}$ as a source of FV. However, the relative inhibition by MMRN1 was mild (as observed earlier using purified $\mathrm{FV}^{29}$ ) and not different between normal FV (17.5\%) and $\mathrm{FV}_{\text {Besançon }}(16 \%)$

\section{4 | DISCUSSION}

FV-deficient patients with FV levels in the $2 \%$ to $5 \%$ range typically present with a mild bleeding tendency, mainly characterized by mucosal and posttraumatic bleeding. ${ }^{50}$ Here, we describe an unusual case of FV deficiency (FV:C 3\%) presenting with recurrent VT instead of bleeding, in the presence of the F2 20210G>A mutation as the only thrombophilic defect. In an attempt to explain this discrepancy, we have performed a detailed functional characterization that helps to better understand the role of FV as a regulator of the hemostatic balance.

The patient's hypercoagulable state manifested as an impairment of the TFPI system and pronounced APC resistance in the thrombin generation test. These abnormalities were particularly striking in PRP, but also evident in PPP. Although the low TFPI $\alpha$ level and the F2 20210G >A mutation may have contributed to these phenotypes, the quantitative and qualitative $\mathrm{FV}$ alterations induced by the $\mathrm{FV}_{\text {Besançon }}$ mutation are also likely to play a role.

Intriguingly, a partial decrease of the FV level affects the anticoagulant functions of FV more than its procoagulant function. In fact, although prothrombinase activity can be supported by traces of $\mathrm{FV}^{32,51,52}$ and is already maximal at $10 \%$ to $20 \% \mathrm{FV}^{3}$ the anticoagulant activities of FV as a cofactor of APC and TFPI $\alpha$ increase throughout the whole FV concentration range and are hardly saturated even at $100 \% \mathrm{FV}^{8,53}$ In addition, $\mathrm{FV}$ deficiency is always accompanied by a reduction of the plasma TFPI $\alpha$ level, ${ }^{3}$ which relieves the anticoagulant pressure on FV activation and prothrombinase activity. ${ }^{14,15}$ With an FV level of $\sim 3 \%$ and a plasma TFPI $\alpha$ level of $24 \%$, our patient can generate sufficient $\mathrm{FVa}$ for prothrombinase, whereas the anticoagulant functions of FV are virtually abolished (as shown by the Immunochrom test for the APC-cofactor activity), partially compensating for the suboptimal prothrombinase activity. However, this applies to all FV-deficient patients with similar FV levels and may explain why these patients do not usually experience major bleeding. ${ }^{3}$

What might distinguish our patient from other patients with similar FV levels is that the $\mathrm{FV}_{\text {Besançon }}$ mutation also alters the functional properties of the residual FV. In fact, the in silico model, the phospholipid titrations of prothrombinase and the striking similarity in thrombin generation between the patient's PPP and FV-depleted plasma reconstituted with $2.8 \%$ FV1 all suggest that the Ala2086Asp substitution in the C2 domain may interfere with FV binding to negatively charged phospholipids. As shown in the model system experiments, this makes $\mathrm{FVa}_{\text {Besançon }}$ a less efficient prothrombinase cofactor than normal FVa (an anticoagulant effect), but it also delays FVa inactivation in the presence of protein $\mathrm{S}$ (a procoagulant effect). Because FVa inactivation has a higher phospholipid requirement than prothrombinase, ${ }^{54}$ the phospholipidbinding defect of $\mathrm{FVa}_{\text {Besançon }}$ is likely to have a greater impact on FVa inactivation than on prothrombinase activity, resulting in a hypercoagulable state.

The importance of optimal phospholipid-binding for FVa inactivation is underscored by the recent finding that membrane-bound FVa and protein S synergistically enhance the binding of APC to negatively charged phospholipids, thereby driving the formation of the FVa inactivating complex. ${ }^{19}$ In model systems of APC-catalyzed $\mathrm{FVa}$ inactivation, $\mathrm{FVa}_{\text {Besançon }}$ was inactivated at a similar rate as normal FVa in the absence of protein S, but somewhat more slowly in the presence of protein S, mainly because of poor stimulation of the $\mathrm{Arg}^{306}$-cleavage by protein $\mathrm{S}$. In this respect, $\mathrm{FV}_{\text {Besançon }}$ closely resembles $\mathrm{FV}_{\text {Nara }}$ (Trp1920Arg), a previously described FV mutation associated with pronounced APC resistance and severe thrombophilia in a patient with partial FV deficiency (FV:Ag 40\%, FV:C $10 \%) .{ }^{36}$ Functional characterization of $\mathrm{FV}_{\mathrm{Nara}}$ led to the conclusion that its resistance to inactivation by the APC/protein S complex is due to defective interactions with both phospholipids ${ }^{19}$ and protein $\mathrm{S}^{19,36}$ Interestingly, the $\mathrm{FV}_{\mathrm{Nara}}$ and $\mathrm{FV}_{\text {Besançon }}$ mutations affect nearly homologous residues of the $\mathrm{C} 1$ and $\mathrm{C} 2$ domains, respectively, causing analogous structural changes and modifying the phosphatidylserine-binding properties of these domains in similar ways (Figure S5, compare with Figure 4). Whether $\mathrm{FVa}_{\text {Besançon, like }}$ $\mathrm{FVa}_{\mathrm{Nara}}$, also binds less well to protein $\mathrm{S}$ remains to be established. More recently, another patient with partial FV deficiency (FV:C $20 \%$ ) and recurrent VT/pulmonary embolism has been reported. ${ }^{55}$ Interestingly, one of the two FV mutations identified in this patient (Arg2108Cys) is located at the tip of spike 2 of the C2 domain and is also predicted to reduce the phospholipid-binding affinity of FV (not shown).

Earlier studies in patients with FV deficiency ${ }^{32}$ and combined FV/FVIII deficiency ${ }^{56}$ have shown that thrombin generation in PRP is a better predictor of the clinical phenotype than thrombin generation in PPP. Similarly, the high thrombin generation and extreme APC resistance measured in our patient's PRP were more representative of the patient's prothrombotic tendency than thrombin generation in PPP and could not be recapitulated by measuring thrombin generation in PPP on platelet lipids, suggesting that the cause of the patient's hypercoagulable state may reside in his platelets. Control experiments provided no evidence that platelet MMRN1, a thrombin generation inhibitor ${ }^{49}$ whose binding site on FV partially overlaps the phosphatidylserine-binding site in the C2 domain, ${ }^{29}$ would bind and inhibit $\mathrm{FV}(\mathrm{a})_{\text {Besançon }}$ less efficiently than normal FV(a). Moreover, mixing control PRP with $25 \%$ of patient's 
PRP (which brings in the patient's "platelet background" but hardly any $\mathrm{FV}_{\text {Besançon }}$ ) did not appreciably increase the thrombin generation or APC resistance of control PRP, suggesting that the patient's platelets do not contain an unusual procoagulant component or inhibitors of APC and/or protein S. On the other hand, thrombin generation in the patient's PRP could be fully inhibited by anti-FV antibodies, confirming its dependence on (platelet) $\mathrm{FV}_{\text {Besançon. }}$. Nonetheless, we cannot fully exclude that other unknown genetic or acquired factors besides $\mathrm{FV}_{\text {Besançon }}$ contribute to the patient's thrombotic tendency, especially considering that the patient is the offspring of a consanguineous marriage, which may have favored homozygosity for recessive traits.

This study has some limitations. First, the use of frozen-thawed PRP is not optimal and may have influenced the thrombin generation results. However, the patient's and control PRP were handled in the same way and the effect of freezing and thawing PRP on thrombin-generation parameters was assessed in control experiments. Second, because of the extremely low expression of re-

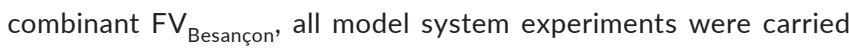
out using diluted plasma as a source of FV. Although this approach has been successfully used before, ${ }^{40}$ an influence of plasma components other than $\mathrm{FV}$ on the investigated coagulation reactions cannot be fully excluded. Finally, the patient's washed platelets were unfortunately not available to study the specific properties of platelet $\mathrm{FV}_{\text {Besançon }}$

In summary, we have identified and characterized a new thrombophilic mutation in $\mathrm{FV}$. We conclude that $\mathrm{FV}_{\text {Besançon }}$ induces a hypercoagulable state via quantitative (markedly decreased FV level) and qualitative (phospholipid-binding defect) effects that affect anticoagulant pathways (anticoagulant activities of FV, FVa inactivation, TFPI $\alpha$ level and activity) more strongly than prothrombinase. Our study supports and provides an explanation for the epidemiological findings that low FV levels ${ }^{57,58}$ and decreased phospholipid-binding capacity of $\mathrm{FV}^{57}$ are strongly and synergistically associated with an increased risk of VT, with individual odds ratios of $>6$ and a combined odds ratio of $21.6 .{ }^{57} \mathrm{~A}$ possible specific role of platelet $\mathrm{FV}$ in this setting deserves further investigation.

\section{ACKNOWLEDGMENTS}

This study was supported in part by the Canadian Institutes of Health Research (CIHR) grant MOP 133474 (C.P.M.H.). Jan Rosing is Van de Laar Professor of Coagulation Enzymology.

\section{CONFLICT OF INTEREST}

Dr. Thomassen and Dr. Hackeng are shareholders of Coagulation Profile BV (The Netherlands). All other authors declare no competing financial interests.

\section{AUTHOR CONTRIBUTIONS}

Elisabetta Castoldi designed and performed experiments, analyzed data, and wrote the manuscript; Nathalie Hézard performed experiments and analyzed data: Guillaume Mourey included the patient and critically reviewed the manuscript; Kanin Wichapong performed the molecular dynamics simulations; Marjorie Poggi performed experiments, analyzed data, and wrote the manuscript; Manal Ibrahim-Kosta performed experiments and critically reviewed the manuscript; M. Christella L. G. D. Thomassen designed and performed experiments; Alexandra Fournel performed experiments; Catherine P. M. Hayward supervised preparation of MMRN1; MarieChristine Alessi designed experiments, analyzed data, and critically reviewed the manuscript; Tilman M. Hackeng critically reviewed the manuscript; Jan Rosing provided advice on experimental design and data interpretation and critically reviewed the manuscript; PierreEmmanuel Morange designed experiments, analyzed data, and wrote the manuscript. All authors have read and approved the final version of the manuscript.

\section{ORCID}

Marjorie Poggi (D) https://orcid.org/0000-0001-6331-9682

Catherine P. M. Hayward (D) https://orcid.org/0000-0002-2843-0817

Marie-Christine Alessi (D) https://orcid.org/0000-0003-3927-5792

Pierre-Emmanuel Morange (D) https://orcid.org/0000-0002-9065-722X

\section{REFERENCES}

1. Dahlbäck B. Pro- and anticoagulant properties of factor $V$ in pathogenesis of thrombosis and bleeding disorders. Int J Lab Hematol. 2016;38:4-11.

2. Tracy PB, Eide LL, Bowie EJ, Mann KG. Radioimmunoassay of factor $\checkmark$ in human plasma and platelets. Blood. 1982;60:59-63.

3. Duckers C, Simioni P, Spiezia L, et al. Low plasma levels of tissue factor pathway inhibitor in patients with congenital factor $\mathrm{V}$ deficiency. Blood. 2008;112:3615-3623.

4. Vincent LM, Tran S, Livaja R, Bensend TA, Milewicz DM, Dahlbäck B. Coagulation factor V(A2440G) causes east Texas bleeding disorder via TFPlalpha. J Clin Invest. 2013;123:3777-3787.

5. Peraramelli S, Thomassen S, Heinzmann A, et al. Role of exosite binding modulators in the inhibition of Fxa by TFPI. Thromb Haemost. 2016;115:580-590.

6. Santamaria S, Reglińska-Matveyev N, Gierula M, et al. Factor V has an anticoagulant cofactor activity that targets the early phase of coagulation. J Biol Chem. 2017;292:9335-9344.

7. Dahlbäck B, Guo LJ, Livaja-Koshiar R, Tran S. Factor V-short and protein $\mathrm{S}$ as synergistic tissue factor pathway inhibitor (TFPlalpha) cofactors. Res Pract Thromb Haemost. 2018;2:114-124.

8. van Doorn P, Rosing J, Duckers C, Hackeng TM, Simioni P, Castoldi E. Factor $\mathrm{V}$ has anticoagulant activity in plasma in the presence of TFPlalpha: difference between FV1 and FV2. Thromb Haemost. 2018;118:1194-1202.

9. Dahlbäck B, Hildebrand B. Inherited resistance to activated protein $\mathrm{C}$ is corrected by anticoagulant cofactor activity found to be a property of factor V. Proc Natl Acad Sci USA. 1994;91: 1396-1400.

10. Shen L, Dahlbäck B. Factor $V$ and protein $S$ as synergistic cofactors to activated protein $\mathrm{C}$ in degradation of factor VIIla. J Biol Chem. 1994;269:18735-18738.

11. Gierula M, Ahnström J. Anticoagulant protein S - new insights on interactions and functions. J Thromb Haemost. 2020;18(11):2801-2811.

12. Monkovic DD, Tracy PB. Activation of human factor $\mathrm{V}$ by factor $\mathrm{Xa}$ and thrombin. Biochemistry. 1990;29:1118-1128.

13. Rosing J, Tans G, Govers-Riemslag JW, Zwaal RF, Hemker HC. The role of phospholipids and factor $\mathrm{Va}$ in the prothrombinase complex. J Biol Chem. 1980;255:274-283. 
14. Wood JP, Bunce MW, Maroney SA, Tracy PB, Camire RM, Mast $A E$. Tissue factor pathway inhibitor-alpha inhibits prothrombinase during the initiation of blood coagulation. Proc Natl Acad Sci USA 2013;110:17838-17843.

15. van Doorn P, Rosing J, Wielders SJ, Hackeng TM, Castoldi E. The C-terminus of tissue factor pathway inhibitor-alpha inhibits factor $\mathrm{V}$ activation by protecting the $\operatorname{Arg}(1545)$ cleavage site. J Thromb Haemost. 2017;15:140-149

16. Kalafatis M, Rand MD, Mann KG. The mechanism of inactivation of human factor $\mathrm{V}$ and human factor $\mathrm{Va}$ by activated protein $\mathrm{C}$. J Biol Chem. 1994;269:31869-31880.

17. Nicolaes GA, Tans G, Thomassen MC, et al. Peptide bond cleavages and loss of functional activity during inactivation of factor Va and factor VaR506Q by activated protein C. J Biol Chem. 1995;270:21158-21166.

18. Walker FJ. Regulation of activated protein $\mathrm{C}$ by protein $\mathrm{S}$. The role of phospholipid in factor $V a$ inactivation. J Biol Chem. 1981;256:11128-11131.

19. Gierula M, Salles-Crawley II, Santamaria S, et al. The roles of factor $\mathrm{Va}$ and protein $\mathrm{S}$ in formation of the activated protein $\mathrm{C}$ / protein S/factor Va inactivation complex. J Thromb Haemost. 2019;17:2056-2068.

20. Rosing J, Hoekema L, Nicolaes GA, et al. Effects of protein S and factor $\mathrm{Xa}$ on peptide bond cleavages during inactivation of factor Va and factor VaR506Q by activated protein C. J Biol Chem. 1995;270:27852-27858.

21. Norstrøm EA, Steen M, Tran S, Dahlbäck B. Importance of protein $\mathrm{S}$ and phospholipid for activated protein C-mediated cleavages in factor Va. J Biol Chem. 2003;278:24904-24911.

22. Ortel TL, Devore-Carter D, Quinn-Allen M, Kane WH. Deletion analysis of recombinant human factor $\mathrm{V}$. Evidence for a phosphatidylserine binding site in the second C-type domain. J Biol Chem. 1992;267:4189-4198.

23. Saleh M, Peng W, Quinn-Allen MA, et al. The factor V C1 domain is involved in membrane binding: identification of functionally important amino acid residues within the $\mathrm{C} 1$ domain of factor $\mathrm{V}$ using alanine scanning mutagenesis. Thromb Haemost. 2004;91:16-27.

24. Macedo-Ribeiro S, Bode W, Huber R, et al. Crystal structures of the membrane-binding $\mathrm{C} 2$ domain of human coagulation factor $\mathrm{V}$. Nature. 1999;402:434-439.

25. Camire RM, Pollak ES, Kaushansky K, Tracy PB. Secretable human platelet-derived factor $\mathrm{V}$ originates from the plasma pool. Blood. 1998;92:3035-3041.

26. Thomassen MC, Castoldi E, Tans G, et al. Endogenous factor $V$ synthesis in megakaryocytes contributes negligibly to the platelet factor $V$ pool. Haematologica. 2003;88:1150-1156.

27. Gould WR, Silveira JR, Tracy PB. Unique in vivo modifications of coagulation factor $\mathrm{V}$ produce a physically and functionally distinct platelet-derived cofactor: characterization of purified plateletderived factor V/Va. J Biol Chem. 2004;279:2383-2393.

28. Hayward CP, Furmaniak-Kazmierczak E, Cieutat AM, et al. Factor $\mathrm{V}$ is complexed with multimerin in resting platelet lysates and colocalizes with multimerin in platelet alpha-granules. J Biol Chem. 1995;270:19217-19224.

29. Jeimy SB, Woram RA, Fuller N, et al. Identification of the MMRN1 binding region within the $\mathrm{C} 2$ domain of human factor V. J Biol Chem. 2004;279:51466-51471.

30. Jeimy SB, Quinn-Allen MA, Fuller N, Kane WH, Hayward CP. Location of the multimerin 1 binding site in coagulation factor $\mathrm{V}$ : an update. Thromb Res. 2008;123:352-354.

31. Camire RM, Kalafatis M, Simioni P, Girolami A, Tracy PB. Plateletderived factor $\mathrm{Va} / \mathrm{Va}$ Leiden cofactor activities are sustained on the surface of activated platelets despite the presence of activated protein C. Blood. 1998;91:2818-2829.
32. Duckers $\mathrm{C}$, Simioni $\mathrm{P}$, Spiezia L, et al. Residual platelet factor $\mathrm{V}$ ensures thrombin generation in patients with severe congenital factor $\mathrm{V}$ deficiency and mild bleeding symptoms. Blood. 2010;115:879-886

33. Bertina RM, Koeleman BP, Koster T, et al. Mutation in blood coagulation factor $\mathrm{V}$ associated with resistance to activated protein $\mathrm{C}$. Nature. 1994;369:64-67.

34. Dahlbäck B, Carlsson M, Svensson PJ. Familial thrombophilia due to a previously unrecognized mechanism characterized by poor anticoagulant response to activated protein C: prediction of a cofactor to activated protein C. Proc Natl Acad Sci USA 1993;90:1004-1008.

35. Castoldi E, Rosing J. APC resistance: biological basis and acquired influences. J Thromb Haemost. 2010;8:445-453.

36. Nogami K, Shinozawa K, Ogiwara K, et al. Novel FV mutation (W1920R, FVNara) associated with serious deep vein thrombosis and more potent APC resistance relative to FVLeiden. Blood. 2014;123:2420-2428.

37. Pezeshkpoor B, Castoldi E, Mahler A, et al. Identification and functional characterization of a novel F5 mutation (Ala512Val, FVBonn) associated with activated protein C resistance. J Thromb Haemost. 2016;14:1353-1363

38. Maurissen LF, Castoldi E, Simioni P, Rosing J, Hackeng TM. Thrombin generation-based assays to measure the activity of the TFPI-protein S pathway in plasma from normal and protein Sdeficient individuals. J Thromb Haemost. 2010;8:750-758.

39. Hemker HC, Giesen P, AIDieri R, et al. The calibrated automated thrombogram (CAT): a universal routine test for hyper- and hypocoagulability. Pathophysiol Haemost Thromb. 2002;32:249-253.

40. Jenny RJ, Pittman DD, Toole JJ, et al. Complete cDNA and derived amino acid sequence of human factor V. Proc Natl Acad Sci USA. 1987;84:4846-4850.

41. Hoekema L, Castoldi E, Tans G, et al. Functional properties of factor $\mathrm{V}$ and factor $\mathrm{Va}$ encoded by the R2-gene. Thromb Haemost. 2001;85:75-81.

42. Váradi $\mathrm{K}$, Moritz $\mathrm{B}$, Lang $\mathrm{H}$, et al. A chromogenic assay for activated protein C resistance. Br J Haematol. 1995;90:884-891.

43. Arnold K, Bordoli L, Kopp J, Schwede T. The SWISS-MODEL workspace: a web-based environment for protein structure homology modelling. Bioinformatics. 2006;22:195-201.

44. Adams TE, Hockin MF, Mann KG, Everse SJ. The crystal structure of activated protein $\mathrm{C}$-inactivated bovine factor $\mathrm{Va}$ : implications for cofactor function. Proc Natl Acad Sci USA. 2004;101:8918-8923.

45. Poort SR, Rosendaal FR, Reitsma PH, Bertina RM. A common genetic variation in the 3'-untranslated region of the prothrombin gene is associated with elevated plasma prothrombin levels and an increase in venous thrombosis. Blood. 1996;88:3698-3703.

46. Rosing J, Bakker HM, Thomassen MC, Hemker HC, Tans G. Characterization of two forms of human factor Va with different cofactor activities. J Biol Chem. 1993;268:21130-21136.

47. Adzhubei IA, Schmidt S, Peshkin L, et al. A method and server for predicting damaging missense mutations. Nat Methods. 2010;7:248-249.

48. Vaser R, Adusumalli S, Leng SN, Sikic M, Ng PC. SIFT missense predictions for genomes. Nat Protoc. 2016;11:1-9.

49. Jeimy SB, Fuller $\mathrm{N}$, Tasneem $\mathrm{S}$, et al. Multimerin 1 binds factor $\mathrm{V}$ and activated factor $\mathrm{V}$ with high affinity and inhibits thrombin generation. Thromb Haemost. 2008;100:1058-1067.

50. Lak M, Sharifian R, Peyvandi F, Mannucci PM. Symptoms of inherited factor $\mathrm{V}$ deficiency in 35 Iranian patients. $\mathrm{Br} J$ Haematol. 1998:103:1067-1069. 
51. Yang TL, Cui J, Taylor JM, Yang A, Gruber SB, Ginsburg D. Rescue of fatal neonatal hemorrhage in factor $\mathrm{V}$ deficient mice by low level transgene expression. Thromb Haemost. 2000;83:70-77.

52. Mann KG. How much factor V is enough? Thromb Haemost. 2000;83:3-4.

53. Castoldi E, Brugge JM, Nicolaes GA, Girelli D, Tans G, Rosing J. Impaired APC cofactor activity of factor $\mathrm{V}$ plays a major role in the APC resistance associated with the factor V Leiden (R506Q) and R2 (H1299R) mutations. Blood. 2004;103:4173-4179.

54. Hoekema L, Nicolaes GA, Hemker HC, Tans G, Rosing J. Human factor Va1 and factor Va2: properties in the procoagulant and anticoagulant pathways. Biochemistry. 1997;36:3331-3335.

55. Sridharan M, Coon LM, Chen D, Pruthi RK. Factor V deficiency with a thrombotic clinical phenotype. Semin Thromb Hemost. 2019;45:108-112.

56. Shao $Y, W u ~ W, X u ~ G$, Wang $X$, Ding $Q$. Low factor $\vee$ level ameliorates bleeding diathesis in patients with combined deficiency of factor V and factor VIII. Blood. 2019;134:1745-1754.

57. Suehisa E, Kawasaki T, Toku M, Hidaka Y. Low level of factor $V$ is associated with development of deep-vein thrombosis in Japanese patients. Thromb Res. 2010;125:128-133.
58. Rietveld IM, Bos MHA, Lijfering WM, et al. Factor $V$ levels and risk of venous thrombosis: the MEGA case-control study. Res Pract Thromb Haemost. 2018;2:320-326.

\section{SUPPORTING INFORMATION}

Additional supporting information may be found online in the Supporting Information section.

How to cite this article: Castoldi E, Hézard N, Mourey G, et al. Severe thrombophilia in a factor $V$-deficient patient homozygous for the Ala2086Asp mutation (FV Besançon). J Thromb Haemost. 2021;19:1186-1199. https://doi. org/10.1111/jth.15274 